Journal of the American Mosquito Control Association, 23(3):335-339, 2007

Copyright (c) 2007 by The American Mosquito Control Association, Inc.

\title{
NONTARGET EFFECTS OF THE MOSQUITO ADULTICIDE PYRETHRIN APPLIED AERIALLY DURING A WEST NILE VIRUS OUTBREAK IN AN URBAN CALIFORNIA ENVIRONMENT
}

WALTER M. BOYCE, ${ }^{1}$ SHARON P. LAWLER, ${ }^{2,3}$ JENNIFER M. SCHULTZ, ${ }^{1}$ SHANNON J. MCCAULEY, ${ }^{2,3}$

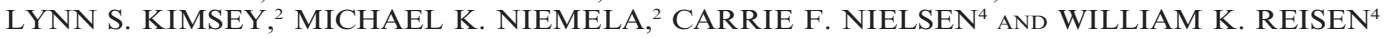

ABSTRACT. In August 2006, a pyrethrin insecticide synergized with piperonyl butoxide (EverGreen ${ }^{\circledR}$ Crop Protection EC 60-6, McLaughlin Gormley King Company, Golden Valley, MN) was sprayed in ultralow volumes over the city of Davis, CA, by the Sacramento-Yolo Mosquito and Vector Control District to control mosquitoes transmitting West Nile virus. Concurrently, we evaluated the impact of the insecticide on nontarget arthropods by 1) comparing mortality of treatment and control groups of sentinel arthropods, and 2) measuring the diversity and abundance of dead arthropods found on treatment and control tarps placed on the ground. We found no effect of spraying on nontarget sentinel species including dragonflies (Sympetrum corruptum), spiders (Argiope aurantia), butterflies (Colias eurytheme), and honeybees (Apis mellifera). In contrast, significantly higher diversity and numbers of nontarget arthropods were found on ground tarps placed in sprayed versus unsprayed areas. All of the dead nontarget species were small-bodied arthropods as opposed to the large-bodied sentinels that were not affected. The mortality of sentinel mosquitoes placed at the same sites as the nontarget sentinels and ground tarps ranged from $0 \%$ to $100 \%$. Dead mosquitoes were not found on the ground tarps. We conclude that aerial spraying with pyrethrins had no impact on the large-bodied arthropods placed in the spray zone, but did have a measurable impact on a wide range of small-bodied organisms.

KEY WORDS Ultra-low volume adulticide, nontarget mortality, pyrethrins

\section{INTRODUCTION}

The West Nile virus (WNV; family Flaviviridae, genus Flavivirus) invasion of North America has seriously impacted human, equine, and wildlife health (Komar 2003, Marra et al. 2003), and it has increased the frequency of ultra-low volume (ULV) adulticide applications to mitigate ongoing or pending outbreaks of disease. Although the adulticides currently in use are considered low risk for effects on vertebrate health, in theory their use could cause mortality of nontarget arthropods, and potentially affect wildlife indirectly by reducing invertebrate prey (Jensen et al. 1999). Conversely, vector control activities may benefit wildlife (especially birds) by reducing WNV transmission within and among wildlife populations.

Adulticides are applied in California if the response risk is elevated to Level 2 (Emergency Planning Conditions) or Level 3 (Epidemic Conditions) (California Department of Health Services 2006). Adulticides that may be used in California include organophosphates (malathion, naled) and pyrethrins (permethrin, resmethrin, sumithrin). Adulticides may pose a greater threat

${ }^{1}$ Wildlife Health Center, University of California, One Shields Avenue, Davis, CA 95616.

${ }^{2}$ Department of Entomology, University of California, One Shields Avenue, Davis, CA 95616.

${ }^{3}$ Center for Population Biology, University of California, One Shields Avenue, Davis, CA 95616.

${ }^{4}$ Center for Vectorborne Diseases, University of California, One Shields Avenue, Davis, CA 95616. to wildlife because they are toxic to a wider variety of nontarget species than bacterial larvicides (Their 2001, Logomasini 2004) and typically are applied over broad areas. Adulticides may be applied in urban or suburban areas to target mosquitoes near people, or they may be applied near wetlands to reduce adult mosquito populations at their source. Larvicides are used most effectively early in the mosquito season before large numbers of adult mosquitoes are present, or during the summer when the extent of surface water is limited. In contrast, adulticides are most likely to be used after human or equine cases occur and when there is an immediate need to interrupt virus transmission.

Transmission of WNV approached epidemic levels in Yolo County, CA, during the summer of 2006. Recognizing that aerial spraying of adulticide was imminent over the urban community of Davis in August 2006, we took advantage of the opportunity to evaluate the effects of adulticiding on nontarget arthropod species. Our specific objectives were 1) to compare mortality between treatment and control groups of sentinel arthropods, and 2) to measure the diversity and abundance of dead arthropods found on treatment and control tarps placed on the ground.

\section{MATERIALS AND METHODS}

\section{Study area and insecticide application}

The city of Davis is located in the Central Valley of California, just west of Sacramento at 
$38^{\circ} 33^{\prime} 14^{\prime \prime} \mathrm{N}, 121^{\circ} 44^{\prime} 17^{\prime \prime} \mathrm{W}$ at an elevation of $16 \mathrm{~m}$. The population of about 60,000 lives in 23,000 households in an urban setting with an extensive network of parks and greenbelts, with abundant tree cover producing a mosaic of open and canopy-covered areas. The city is surrounded by irrigated farmland.

Culex tarsalis Coq. is abundant in the agricultural areas around Davis, whereas Cx. pipiens L. is found within the urban habitat. Both species are competent vectors of WNV (Goddard et al. 2002). In response to elevated WNV infection rates in these vector mosquitoes, a marked increase in the number of dead corvids reported by the public, and the onset of human cases during late July and August 2006, the Sacramento-Yolo Mosquito and Vector Control District conducted aerial spraying to decrease virus transmission. Aerial application took place just after sunset on August 8 and 9. The pyrethrin insecticide, synergized with piperonyl butoxide (EverGreen ${ }^{\circledR}$ Crop Protection EC 60-6, McLaughlin Gormley King Company, Golden Valley, MN) was applied at $0.0025 \mathrm{lb} / \mathrm{acre}$ (maximum label rate for mosquito control) in ultra-low volumes over the entire city by a twinengine aircraft flying approximately $95 \mathrm{~m}$ above ground while winds were $<10 \mathrm{~km} / \mathrm{h}$.

\section{Sentinel arthropods}

Target species: Two hoop-style sentinel cages (Townzen and Natvig 1973), each containing 2135 field-collected adult $C x$. tarsalis, were placed perpendicular to the wind in exposed and sheltered settings at each of 21 previously established mosquito surveillance locations in Davis, as well as at 10 control sites established outside of the Davis spray zone. Sentinels were placed in the field just prior to evening insecticide application and retrieved within $2 \mathrm{~h}$ after application. Cages were placed in individual plastic bags with wet toweling and cotton plugs wetted with $10 \%$ sugar water. Mortality was recorded at the time of collection and again about $8 \mathrm{~h}$ after insecticide exposure.

Nontarget species: Sentinel dragonflies (Sympetrum corruptum Hagen, 1861) and yellow garden spiders (Argiope aurantia Lucas, 1833) were evaluated when spraying occurred on August 8, and alfalfa butterflies (Colias eurytheme Boisduval, 1852) and honeybees (Apis mellifera L., 1758) were evaluated when spraying occurred on August 9. Twelve treatment sites were selected from the 21 previously established mosquito surveillance sites to provide broad geographic coverage of the city. Corresponding control sites were established approximately $3 \mathrm{~km}$ west of the Davis spray zone (non-Davis control sites). Dragonflies, spiders, butterflies, and bees were captured within the proposed spray area in the $24-\mathrm{h}$ period prior to aerial spraying. They were housed in protective containers in a cool, dark area and placed in the field within $2 \mathrm{~h}$ of the start of the aerial insecticide application. They were removed from the field just prior to sunrise the next morning, examined, and recorded as live or dead.

Dragonflies were housed separately in mesh net enclosures. Three individuals were placed at each of 10 treatment sites, and 6 or 7 at 3 nonDavis control sites. Two enclosures at treatment sites were vandalized, reducing dragonfly sample size from 30 to 28 . Yellow garden spiders were housed individually in hoop-style cages identical to those used for mosquito sentinels. Two individuals were placed at each of 10 treatment sites, and 6 or 7 at each of 3 non-Davis control sites. Alfalfa butterflies were housed in groups of 3 in mesh net enclosures at each of 9 treatment sites. Controls consisted of 27 butterflies ( 9 groups of 3 ) placed at a single treatment site and covered with plastic bags. Honeybees were housed in pairs in hoop-style cages. Two cages were placed at each of 12 treatment sites, and 1 cage at each site was covered with a plastic bag to serve as a control.

\section{Diversity and abundance}

We measured the diversity and abundance of dead arthropods found on muslin tarps placed on the ground before and after aerial application of pyrethrin. Twenty $1 \times 2-\mathrm{m}$ tarps were placed overnight at 10 of the established treatment sites on August 2 when spraying was canceled due to breezy conditions, and again on August 8 when spraying occurred. The August 2 sampling was used as a Davis control group, and samples collected following spraying on August 8 were used as the Davis treatment group. Twenty identical tarps were also placed outside of the Davis spray zone (non-Davis control) at 3 locations ( 7 at 2 sites and 6 at 1 site) the night of spraying. The tarps were located at the same sites as the sentinel arthropods and were positioned at the boundary between canopy and exposed areas. Tarps were placed on the ground within $2 \mathrm{~h}$ of sunset and removed just prior to sunrise and examined. Any dead arthropod was retained and later identified as to order and family; live arthropods found on tarps were released.

\section{RESULTS}

The survival of sentinel arthropods at treatment and control sites is shown in Table 1. There was $100 \%$ survival of dragonflies and spiders, and chi-square analysis indicated no significant difference in survival of butterflies $(P=0.055)$ or honeybees $(P=0.125)$ in sprayed and unsprayed control areas. All surviving arthropods were capable of normal flight (dragonflies, butterflies, 
Table 1. Survival of sentinel arthropods at treatment and control sites. Aerial applications of pyrethrin synergized with piperonyl butoxide occurred on August 8-9, 2006, in Davis, CA.

\begin{tabular}{lccc}
\hline \hline $\begin{array}{c}\text { Common } \\
\text { name }\end{array}$ & Species & $\begin{array}{c}\text { Treatment } \\
\text { \% survival }\end{array}$ & $\begin{array}{c}\text { Control } \\
\text { \% survival }\end{array}$ \\
\hline Dragonfly & $\begin{array}{c}\text { Sympetrum } \\
\text { corruptum }\end{array}$ & 100 & 100 \\
$\begin{array}{c}\text { Yellow garden } \\
\text { spider }\end{array}$ & $\begin{array}{c}\text { Argiope } \\
\text { aurantia } \\
\text { Colias } \\
\text { eurytheme } \\
\text { butterfly }\end{array}$ & 100 & 100 \\
$\begin{array}{c}\text { Honeybee } \\
\text { Mosquito }\end{array}$ & $\begin{array}{c}\text { Apis mellifera } \\
\text { Culex tarsalis }\end{array}$ & 75 & 100 \\
\hline
\end{tabular}

honeybees) or movement (spiders) upon their release back into the environment. The mortality of sentinel mosquitoes within the spray zone was variable among exposed locations $(10-100 \%)$, but was significantly $(\mathrm{F}=13.4, \mathrm{df}=1,18, P=0.002)$ greater in exposed cages than in cages placed under vegetative canopy (Table 2). There was no mortality among sentinel mosquitoes at the control sites (Table 1).

In contrast to the results of the sentinel study, significantly $(P<0.001)$ higher diversity and numbers of nontarget arthropods were found dead on tarps in the treatment sites versus the Davis and non-Davis control sites (Table 2). All of the dead nontarget species were small-bodied arthropods belonging to $>25$ families in the following orders: Blatodea, Coleoptera, Collembola, Diptera, Hemiptera, Hymenoptera, Pscoptera, Thysanoptera, Acari, and Araneae. There was no apparent relationship between mortality of sentinel mosquitoes and mortality of nontarget species among sampling sites. No dead mosqui- toes were found on the tarps placed in treatment or control sites.

\section{DISCUSSION}

We conducted this study to shed light on whether or not there were detectable impacts on nontarget arthropods when pyrethrin synergized with piperonyl butoxide was aerially applied to an urban community to control WNV transmission. We found no effect of spraying on relatively large-sized sentinel arthropods, including dragonflies, spiders, butterflies, and honeybees (Table 1$)$. In contrast, significantly $(P<$ $0.001)$ higher diversity and numbers of non-target arthropods were killed in the treatment versus control groups (Table 2). All of the dead nontarget species were small-bodied arthropods, as opposed to the large-bodied sentinels that were not affected. We conclude that aerial spraying had no impact on the large-bodied arthropods placed in the spray zone, but did have a measurable impact on a wide range of small-bodied organisms.

We placed our nontarget sentinel cages and the ground tarps at the same locations at the edge of the canopy next to open areas, so both were exposed to similar levels of adulticide. The dead organisms found on the tarps either fell from overhanging branches, dropped from midair, or crawled onto the tarp and died. The greater ratio of surface area to body mass for the small-bodied arthropods may partially explain why they had higher mortality than the large-bodied sentinels.

The mortality of sentinel mosquitoes placed at the same sites as our nontarget study ranged from $0-100 \%$ and no dead mosquitoes were found on the tarps. As expected, the survivorship of sentinel mosquitoes was significantly $(P<$

Table 2. Mortality of sentinel mosquitoes and free-flying or moving nontarget arthropods at treatment and control sites before and after aerial application of pyrethrins on August 8, 2006, in Davis, CA. Twenty $1 \times 2-\mathrm{m}$ tarps were placed overnight at 10 locations (2/site) in Davis 6 days prior to spraying (Davis control) and the night of spraying (Davis treatment). The tarps were placed at the boundary between canopy and exposed areas relative to the sentinel mosquitoes. Mean numbers were compared by $t$-tests.

\begin{tabular}{|c|c|c|c|c|c|c|c|c|}
\hline \multirow[b]{2}{*}{ Site } & \multicolumn{2}{|c|}{$\begin{array}{l}\text { Sentinel mosquito } \\
\text { mortality } \%\end{array}$} & \multicolumn{2}{|c|}{$\begin{array}{l}\text { No. of orders of } \\
\text { dead arthropods }\end{array}$} & \multicolumn{2}{|c|}{$\begin{array}{l}\text { No. of families of } \\
\text { dead arthropods }\end{array}$} & \multicolumn{2}{|c|}{$\begin{array}{c}\text { No. of } \\
\text { dead organisms }\end{array}$} \\
\hline & Canopy & Exposed & Treatment & Control & Treatment & $\overline{\text { Control }}$ & Treatment & Control \\
\hline A19 & 26.1 & 96.3 & 4 & - & 5 & - & 6 & - \\
\hline B 13 & 14.3 & 96.2 & 3 & 1 & 3 & 1 & 7 & 1 \\
\hline $\mathrm{C} 10$ & 16.7 & 22.7 & 2 & - & 2 & - & 44 & - \\
\hline D7 & 12.5 & 58.3 & 5 & 1 & 7 & 1 & 13 & 2 \\
\hline E4 & 15.4 & 69.0 & 3 & 2 & 5 & 2 & 19 & 3 \\
\hline F5 & 18.2 & 65.2 & 4 & 3 & 4 & 3 & 7 & 13 \\
\hline G6 & 0 & 100.0 & 5 & - & 9 & - & 151 & - \\
\hline H11 & 8.0 & 9.7 & 3 & - & 6 & - & 37 & - \\
\hline I14 & 27.3 & 32.0 & 8 & - & 10 & - & 20 & - \\
\hline $\mathrm{J} 12$ & 13.0 & 15.4 & 7 & - & 8 & - & 24 & - \\
\hline Mean & 15.2 & 56.5 & 4.4 & 0.7 & 5.9 & 0.7 & 32.8 & 1.9 \\
\hline$P$ value & $<0.005$ & & $<0.001$ & & $<0.001$ & & $<0.001$ & \\
\hline
\end{tabular}


0.005) higher under vegetative canopy than in exposed areas (Table 2). The canopy cover created by trees and shrubs likely provides a protected environment that may partially or completely shield arthropods from contact with the aerially applied insecticide (Mount et al. 1996, Lothrop et al. 2002). From a vector control perspective, this means that it is difficult to achieve high mosquito kill rates beneath extensive canopy cover. From an ecological perspective, this means that a substantial proportion of the nontarget arthropod populations in and under canopy cover are shielded from exposure. Although our study did not measure populationlevel impacts, we speculate that nontarget impacts in heavily vegetated areas like Davis will not be significant unless an organism has a very restricted spatial distribution, occurs only in exposed habitats (i.e., grassland areas), and is highly susceptible. Threatened and endangered species would be a particularly important focus for future research that attempts to address impacts of aerially applied insecticides on population numbers or persistence.

We believe the experimental design of the sentinel study was robust and would have detected large impacts had they occurred. The application of ULV adulticides was done after sunset to maximize exposure of night-flying mosquitoes and minimize pesticide contact with diurnally active nontarget species. With the exception of yellow garden spiders, all of the nontarget sentinels we used were diurnal species that should not be active at night. However, some level of exposure may occur depending on where organisms spend the night, and we attempted to mimic natural exposure by placing sentinel cages at the canopy edge. Dragonflies and butterflies perch in vegetation at night, so placement of their cages at the edge of vegetative canopy (rather than deep inside) provided maximum natural exposure to drifting insecticide. Yellow garden spiders spin their webs in exposed areas very similar to where the sentinel cages were placed, and we had dozens of naturally occurring spiders located near our sentinel spider cages (these also appeared unaffected after spraying). Our placement of sentinel honeybees was highly artificial and presumably exposed them to more insecticide than would naturally occur, because both commercial and feral honeybees enter highly protected colony locations at night. We were somewhat surprised that sentinel honeybees were not sensitive to this level of exposure (Caron 1979). We infer that the high survivorship of sentinel species reflects high survivorship among naturally occurring populations of these species within these habitats in the spray zone.

Although sentinels were not affected, there was a wide diversity of small-bodied organisms found dead on the ground tarps, including representa- tives from 10 orders and $>25$ families of arthropods. These nocturnal and diurnal species included scavengers, predators, and plant feeders that normally occur in a variety of microhabitats ranging from the soil surface to overhanging vegetation. Although the diversity of affected species was high, the overall numbers of any given taxon were quite low. The one exception was Argentine ants (Hymenoptera: Formicidae), which were the most abundant dead organisms detected. We do not know why this nonnative species of ant was so abundant in our sampling.

The contrasting results of the sentinel study and the ground tarps illustrate the importance of using different approaches to detect impacts on nontarget species. We view our findings as meaningful, but we strongly encourage other investigators to repeat these studies. The impacts of WNV on wildlife (vertebrate and invertebrate) will not occur in isolation from vector control activities, and additional, carefully controlled studies are needed to more fully understand the short- and long-term impacts on nontarget species.

\section{ACKNOWLEDGMENTS}

We thank Sarah Wheeler and Veronica Armijos for assistance with staging the mosquito sentinels, and Karl Mogel for providing honeybees. Sentinel hoop cages were donated by the Sacramento-Yolo Mosquito and Vector Control District, and we thank David Brown, Gary Goodman, Marcia Reed, Stan Wright and the entire Laboratory staff of the District for their help in collaborating with this project. Funding was provided by the University of California Davis Wildlife Health Center.

\section{REFERENCES CITED}

California Department of Health Services. 2006. California mosquito-borne virus surveillance and response plan [Internet]. Available from the California West Nile Virus Website-Resources [accessed June 8, 2007], http://www.westnile.ca.gov/resources.php.

Caron DM. 1979. Effects of some ultra low volume mosquito abatement insecticides on honey bees. $J$ Econ Entomol 72:148-151.

Goddard LB, Roth AE, Reisen WK, Scott TW. 2002. Vector competence of California mosquitoes for West Nile virus. Emerg Infect Dis 8:1385-1391.

Jensen T, Lawler SP, Dritz DA. 1999. Effects of ultralow volume pyrethrin, malathion, and permethrin on non-target invertebrates, sentinel mosquitoes, and mosquitofish in seasonally impounded wetlands. $J \mathrm{Am}$ Mosq Control Assoc 15:330-338.

Komar N. 2003. West Nile virus: epidemiology and ecology in North America. Adv Virus Res 61:185234.

Logomasini A. 2004. Pesticides and the West Nile virus: an examination of environmentalist claims [Internet]. 
Available from the Competitive Enterprise Institute, Washington, DC [accessed June 8, 2007], http:// www.cei.org/pdf/3893.pdf.

Lothrop HD, Lothrop B, Reisen WK. 2002. Nocturnal microhabitat distribution of adult Culex tarsalis (Diptera: Culicidae) impacts control effectiveness. $J$ Med Entomol 39:574-582.

Marra PP, Griffing SM, McLean RG. 2003. West Nile virus and wildlife health. Emerg Infect Dis 9:898-899.
Mount GA, Biery TL, Haile DG. 1996. A review of ultra-low volume aerial sprays of insecticide for mosquito control. J Am Mosq Control Assoc 12: 601-618.

Their A. 2001. Balancing the risks: vector control and pesticide use in response to emerging illness. $J$ Urban Health 78:372-381.

Townzen KR, Natvig HL. 1973. A disposable adult mosquito bioassay cage. Mosq News 33:113-114. 